\title{
The Short Vowels in Islamic Texts
}

\author{
Anne Eudoxie Francisse
}

\section{Iqrā'! Read! Proclaim!}

Vowels (tahrik) are the life of the Arabic language; they breathe in its spirit $(r \bar{u} h)$. Vowels are the dynamic of the word; they regulate its meaning and determine for the verb its active or passive voice. Vowels are nonlocal; "a speech sound produced without occluding, diverting, or constructing the flow of air from the lungs," as opposed to consonants, which do all of the above. Consonants are local. They are the only letters found in Arabic texts, whether handwritten or printed, as in the time of the Jahiliyah. Why? We deplore it in the multifold way of our multidisciplinary approach, for we are not living in the very intensive oral tradition of the Jâhiliyah. Space, time, and communication have demands these days.

The Qur'an and the Sunnah, those unsullied fountainheads of Islam, have reached us completely vowelized. This paper is a "complimentary" plea for bringing life (rüh) to the Arabic Islamic texts by marking the short vowels for the sake of those members of the ummah who are in the process of learning it.

In his last address, the Prophet evoked "a law which you should preserve and be firmly attached to, a law clear and positive: The Book of God and the Sunnah."

At the end of his life, Muhammad (pbuh) had about 30,000 contemporaries who had heard and memorized the Qur'an in whole or part. Several of them could read and write and had committed the Qur'an to writing in part or in toto .... All the revelations written by the Prophet's scribe were collected and stored in the house of 'Á'isha, the Prophet's wife and daughter of Abū Bakr, the first caliph."

Twelve years later, 'Uthmān, the third caliph, felt the need to compile a standard copy of the Qur'an that would ensure the uniform pronunciation of the Qur'anic text throughout the world. During his rule, Islam had spread far and wide in distant lands inhabited by diverse nationalities. The differ-

Anne Eudoxie Francisse is a fellow of the Intemational Institute of Islamic Thought (IIIT), Herndon, Virginia, and a senior member of the Association of Muslim Social Scientists (AMSS). This paper was presented at the 23rd Annual AMSS/IIIT Conference held at SUNY-Binghamton, New York, October 1994. 
ence of pronunciations and dialects in Arabic led to a variety of Qur'anic recitations. In order to avoid differences in versions, all unauthentic copies were burnt after the completion of 'Uthmān's compilation. ${ }^{4}$ Such care for true precision is a historical legacy about which people should take the time to reflect.

So there is no history of the text of the Qur'an. Nor can there be one other than that which traces the shape and use of diacritical marks and calligraphic forms . ... One of the five copies canonized by Uthman in 28 A.H./648 A.C. was made up of separate consonants with no vowels.

In the same perspective of unity and precision,

the process of preservation and instruction of new non-Arabicspeaking converts brought new demands for improving the script and refining its rendering. Until the seventh century, Arabic letters had been written separately. Gradually, rules were established for linking many of them. Pointing was added in order to distinguish between those letters rendered by a single letter (i.e., $b \vec{a}^{\prime}, t \bar{a}^{\prime}, t h \bar{a}^{\prime}$ ). Short vowel markings above and below the letters (the fathah for a short "a" sound, the dammah for a short "u" sound, and the kasrah for a short "i") were developed to complement the consonants and long vowels in the eighth century c.E. They are essentially those that are in use today. Precise methods for indicating diphthongs, the hamzah (glottal stop), the mäddah (vowel prolongation), shaddah (double consonant), and sukūn (vowelless consonant) were also added later. ${ }^{6}$

In that very same way of refining the rendering of Arabic texts designed to be read, broadcasters now have their Arabic texts vowelized before they read them on the air. They are the highlights of Arabic usage.

For the last fourteen centuries, copies or authors, like contemporary writers, could go faster by not marking short vowels. Henceforth, "texts were without mistake." Such an argument is still raised today, despite the possible loss of the precise meaning of the author's message. We are far away in time from the strong oral tradition or "Arabic verbal decor" around the globe.

This paper seeks to dispute the cliché that "all ambiguities may be solved from the context." Educated speakers of Arabic read Arabic Islamic texts in the city. Even the elite circle of Arabs that have graduated from institutions of higher learning in the Western world would be nourished by the memorization of the cornerstone of Arabic expression and literature. Hans Wehr, in his introduction to A Dictionary of Modern Written Arabic, describes how poets and authors would refer to them freely to the delight of Arabs with a traditional background. Still, archaic words would not be recognized: 
Every period of Arab history has had its own peculiar vocabulary which should be set forth in a separate dictionary ... . Arabic phonology, morphology and syntax have remained unchanged from earlier times. Traditional adherence to ancient linguistic norms, to the models of classical literature, especially the Qur'an, has had the effect of preserving the language intact over the centuries.

The Holy Qur'an is our grammar. Yet Țāhā J. al-'Alwānī, in his The Ethics of Disagreement in Islam, specifies that causes of differences of opinion in most cases hinge upon linguistic and juristic interpretations of Qur'anic texts and the Sunnah. Apart from the different meanings of a word or expressions that can be both literal and figurative, linguistic difficulties arose over questions of grammar.

The varying ways of interpreting both positive and negative commands (guidance, warning, news, command) have contributed to differences among jurists in their approaches and in their methods of deriving laws from the Qur'anic text. Sometimes scholars may be at variance on the contextual use of words, even if they fully agree upon the meaning of the words. A case in point is the difference over the Sürat al Baqarah 2:282 which deals with the role of the scribe and the witness in the recording of business transactions.

One interpretation, based on the reading of Ibn 'Abbās, gives the meaning of the verse as: "And let neither the scribe nor witness cause harm." This interpretation takes the verb as being grammatically in the active voice: the scribe is taken to be guilty of writing something different from what had been dictated to him, and the witness guilty of giving false testimony.

Another interpretation, based on a reading of Ibn Mas'ūd, gives the meaning of the verse as: "And let neither scribe nor witness suffer harm." This interpretation takes the verb to be grammatically in the passive voice: both the scribe and the witness might have harm done to them if they were forced to write or testify at a time when it was not convenient for them to do so. Harm could also come to a scribe and a witness, for example, by being held responsible for the eventual consequences of the contract as such, or for the nonfulfillment of any of its provisions by either of the contracting parties. ${ }^{8}$

This latter interpretation may have the comprehensive meaning of the passive and active voices. The factors evoked by either author brings about our reflection. Ibn 'Abbās's interpretation, assuming the guilt of the scribe and witness, as if they were born sinners, shows up a backlash of some endured encounters pertaining to the Christian world. 
We read Qur'an 2:282 further:

Let a scribe write down faithfully as between the parties; let not the scribe refuse to write: as Allah has taught him so let him write.

The importance of the scribe is also explained in note 330 of 2:282:

The scribe in such matters assumes a fiduciary capacity. He should therefore remember to act as in the presence of Allah, with full justice to both parties. The art of writing he should look upon as a gift from Allah, and he should use it as in His service. In an illiterate population the scribe's position is still more responsible.'

The International Institute of Islamic Thought (IIIT) has entered into the firm grasp of the precious treasures of the Islamic legacy..$^{10}$ Striving on kaläm and the concept of free will, we are striving on unvowellized texts. IIIT should realize the important function of a completely vowelized text as a tool of research and should publish all Arabic Islamic texts in a vowelized manner to aid non-Arabic speakers who are learning Islam.

The alleged comfortable argument that all ambiguities are worked out from the context is torn asunder by a range of factors spelled out in any linguistics course in the fields of neurolinguistics, sociolinguistics, and psycholinguistics. The solution is the complete representation of the Arabic language as a safe tool for proper utterance and competence for the sake of communication.

According to Fromkin and Rodman, "Our unique genetic ability to acquire language is revealed only when we receive adequate linguistic stimulus." "And Chopra wrote:

Language as the maker of reality, for insights, for healing, for knowledge, language for wisdom, language for healing, language for creating a new material reality. Language is the force of information and energies which created something out of nothing .... "Let there be Light" equals an infinite amount of sounds/words .... Language is a purely human fate. Language shapes our belief, attitudes and behavioral responses, and the making of reality. ${ }^{12}$

To keep up with the unique quality of the human being, vowelization is indeed an adequate linguistic stimulus.

The contemporary Muslim reader of Arabic texts is placed in a specific setting, now as in the past, that originates the capacity of possible perception. He/she is exposed to demonization, political agitation, massacre, harassment, bombing, "ethnic cleansing," "blotting out of intelligence and degrading of the target," sacking of cities and the treasures of culture, stress scavengers, interference, and obstruction. How reduced his/her capacity to figure out a context! Vowelization would be a great help. 
The diaspora may help. Should you consider part of the intellectual diaspora to be students who go to the Middle East, to al-Azhar University, seeking knowledge in the fields of Arabic and Islamic studies as in the earliest times. My personal experience auditing classes at the College of Islamic and Arabic Studies (women's section) is made up of vocal Arabic and Muslim environments, radiating a vibrant inner circle of students as well as motivated faculty members. I would recognize the words of the mass media because I had heard the news on the radio or could read the text I heard during lectures. At one point, I presumed that the question of vowelization raised in the classroom was not urgent, for the environment was taken for granted. When I returned to the state of Washington, however, after two and a quarter years in Cairo, I had plenty of time to ponder unvowelized texts. Therefore, I now raise the plea for marking short vowels on behalf of those who are learning, pilgrims who go to the Middle East for knowledge, and for the ummah in general.

But it is in the diaspora where one encounters arguments against it, from faculty members who teach Arabic and produce textbooks. I remember a saying:

And now you leave off short vowels and write like those who "normally" keep most printed and all handwritten Arabic unvowelled. Most printed and all handwritten is normally unvoweled. As a rule, only the Koran, the Bible and elementary school books are fully voweled. ${ }^{13}$

I question the word "normally." At the risk of reaching the frontiers of comparative linguistics, I question the "preverbal stage" of Arabic texts that are "consonants only." In English, one hears of the necessity to "cross your t's and dot your i's." In French, "mark your accents neatly" and "your punctuation" is a mark of literacy for making the text acceptable. Also in Western languages, "brush up your German, French, English: Read" is common. But in Arabic, one has no vowels and becomes perplexed. Thus, one does not brush up on vocabulary or grammar. As communication is an easy flow of interaction, vowelized Arab texts should become the norm for brushing up one's Arabic and acquiring knowledge.

Looking over fourteen centuries of Islamic history, one can consider the circumstances of the assassination of 'Uthmān, who decided to compile the standard Holy Qur'an. The atmosphere of political agitation and uncertainty inserted terror in the minds of the population, which reacted with a more protective inner circle of learner policy to save and preserve whatever knowledge they had of the Prophet's Sunnah. They were wary of attempts to corrupt or fabricate traditions. So the Sunnah itself is vowelized, but its commentary and the entire literature about the two books is not.

Was it a fear of democracy that led to a policy of discarding the eighthcentury vowel marks? Al-Ghazzāli, who climbed up the ladder of knowledge in the twelfth century C.E. (d. 505 A.H./1111 C.E.) through the school- 
ing offered to the poorest by the richest people, could settle down with such an opinion at the peak of his career: "True philosophy, in its own nature, was not for the common man." What is a common man nowadays: A man on the street who can read, write, speak the language, and go to a public library. He cannot climb the ladder of knowledge without vowels. "Whether in stark individualism or in ambivalent sectarianism, falsafah protected itself with the veil of secrecy.... They would not allow "the ordinary populace' to experiment with actual philosophical freedom."14

Is the saying pertaining to sociolinguistics, still timely and especially when, in the seventeenth century C.E., the intellectual incursion of Orientalists, colonialists, and missionaries launched attacks "so ensnaring the hearts and minds of many Muslims and clouding their Islamic vision," Muslim treated Islamic thought as an "ancient phenomenon?"15 Should the alleged "sleeping" centuries of enforced colonialism with a modern enforced unawareness sustain the missing vowel marks in the Arabic press? Obscurantism and obstruction are to be fought with skills and neat representation and utterance of the Arabic language. Women emerge from centuries, if not millennia, of silence: Their incentive is to "speak up." Muslimah, recite (iqrā'). Thus, Muslimahs and Muslims should "vocalize" and fight on-we contemporaries, we learners of the ummah-or else we subscribe to the illiteracy that is declared to be the plague of the Third World, Muslim countries included.

What is illiteracy? The alleged illiteracy in Muslim countries comes from a lack of incentive to keep up with reading or the basics of the Arabic language. A vicious circle is enlarged for illiterate people, the real poor ones, who are taken advantage of widely. The madrasah teaches the Qur'an and the Sunnah, but only in the form of memorizing the holy texts. Do they not know from the last address of the Prophet:

Treat women well; they are your helpmates and can do nothing by themselves. You have taken them from Allah on trust. O people! Listen to my words and fix them in your memory.

But public schools in Egypt have their elementary grade books unvowelized after the fifth grade. A student leaving school at that time would depend on the talk around him, television, or the radio to guess at the Arabic press. The adult's behavior is reduced permanently to a behavior of second-language acquisition. Children who are better off may go to private schools for the sake of learning English, "the golden bait." Private schools are like foreign enclaves; they do not teach natives their own cultural roots, for they serve the special interests of their operators, be they French, Roman Catholic, Christian, or otherwise.

Now Islam is tawakkul, seeking knowledge for the sake of God, renaissance, and democracy. Education is democracy. Iqrä' is the first word of the last revelation. Therefore, proclaim, read, rehearse, write as Allah taught by the pen. So if you keep mute about unvowelized texts, you may as well say: 
"Grin, groan, mumble, mutter, moan. There is no mistake in the Text!" Are you alive and well? So please write it out vowelized. Proclaim!

Read in the name of your Lord who created, created humans from a clot. Read! For your Lord is most Bountiful, He who taught by the pen, taught humans what they did not know. Nay, but Man does transgress all bounds. In that he looks upon himself as self-sufficient. Verily, to thy Lord is the return (of all). (96:1-8)

The All-Merciful! (who) taught the Qur'an, created mankind, and taught them expression. (55:103)

Discussing the reality and importance of the Islamization of Knowledge, al-'Alwānī analyzed the imbalance of improper reading:

From the above verses, it may be deduced that humanity has been commanded two different kinds of readings and to understand its situation in the universe through an understanding of how the two complement one another. The first reading is the book of Allah's revelation (the Qur'an), in which all matters of religious significance are explained (12:111) and the second is the book of His creation (the natural universe), from which nothing has been omitted (6:39 and 59) ... . Indeed, any disruption in any aspect of human life is an indication of imbalance in the way the readings were undertaken .... Each reading must be considered an epistemological fundament and a creative source that may not be ignored .... . A society that ignores the first reading in favor of the second will lose sight of its relationship to God and its responsibilities of stewardship, trust, and accountability to a higher authority. The result is a society that grows self-centered and overweening and comes to believe that it is independent and free of the Unseen ... .

It may happen that the second reading, that of the real-existential is ignored by those undertaking the first reading (the revelation). When this happens, great imbalances result, such as the development of an aversion to the world and worldly pursuits that will encourage people to become ascetics and lose the ability to participate in and contribute to society. As a result, individuals will fail to undertake their responsibilities as stewards and keepers of God's trust. In other instances, such a loss of equilibrium will deprive people of the ability to engage in independent and creative thought. When people begin to believe that human beings are not really capable of independent actions, they no longer value their own deeds, and, ultimately, conclude that there is no meaning to their existence. 
The Islamization of Knowledge may be brought about, through combined readings of the two books and the establishment on the basis of their similarity and complementarity, of a methodology for research and discovery. Indeed the Qur'an, like the natural universe, bespeaks and directs towards the other: The Qur'an is a guide to the real-existential, and the real-existential is a guide to the Qur'an. ${ }^{16}$

Such an explanatory display of the two readings and their complementarity makes us posit that the refinement of rendering the Arabic language that took place in the eighth century C.E., for the Qur'an may now, at the end of the twentieth century C.E., be applied to the second reading and all the literature about the first reading.

\section{Examples}

The fathah, the dammah, the kasrah, the sukün (absence of vowel), and the shaddah (letter doubling) make up seven ways of reading the calligraphy ifala as well as fáalä. University courses do not use vowelized texts. Whenever there is a discussion about the morphology or a wording, its sound is spelled out in the text and during the lecture to communicate the vowelization of the unvoweled calligraphy: فعلى fu'alā, fu'lā, fa'alāa, fa'lā, fi'allā, fi'lā, fu'ullā."

Each form of the älif maqșūrah may be a mașdar, a singular or a plural besides an allegedly not important form for geographic location or birds. What baiting will select an alleged scientist for inquiry about a bird, and what unvoweled answer may he receive for an official response?

مصر Mișr or mudār? A xeroxed sukūn may look like a dot over the letter șäd. Without vowelization, one cannot guess the name of the printer; mudār is said to be the language of the Arabs.

شرك Sharaka: sharika: to participate; shirkun: polytheism, idolatry; sharakun: trap; shurukun, plural noun of sharakun (trap) and shirak (shoelace); as an adjective: spurious, false. The idea of trapping may permeate the five voweled words, but each one is specific.

تدرج Tadāraja: of the forty-seven ways of reading tadāraja, here are some of them: tadrujun: pheasant (three cases of declension); stem I, tadru$j u$ from daraja (imperfect active third person feminine and second person masculine) to proceed tadrija from daraja, to rise step by step; stem II: tudarriju, active imperfect third person feminine and second person masculine; stem IV: tudriju, imperfect third person feminine and second person masculine; stem V: tadarrujun, mașdar (three cases of declension); tadarraja, active perfect, third person masculine; tadarraj, imperative singular masculine.

نقرة Naqratah: naqrutun: drumbeat, blow; nuqratun: cavity, eye socket; niqratun, quarrel.

رحلة Ruhlatun (destination) or rihlatun (travel, tour). In these two examples, one's fate depends upon grasping the first syllable, or there 
may be a problem. In colloquial dialect,the last syllables are dropped, so, as in written Arabic, one is perplexed in the absence of written-out vowels.

جود Jüdun or Jawdun. It all depends on the sukūn in the second wording. Is it "openhandedness" (with the long wāw) or a "heavy rain" (with a sukūn over the $\left.j \bar{a}^{\prime}\right)$ ?

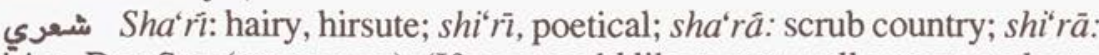
Sirius, Dog Star (astronomy). (If one would like to test well-meant students, ask them to vowelize Sürat al-Najm 49. In the mass media, they use either form).

نور Nawrun: blossom; nawwara (stem II active perfect): to blossom; nuwwira (stem II, passive perfect); nūr: light beam, brightness; nawar: gypsies, vagabonds (colloquial).

j Dhakarun: male; dhikrun: memory, invocation of God; dhakara: to think, remember; dhukira (passive form of perfect) to be indicated; dhakkara (stem II active perfect): to remind, to make masculine (grammar); dhukkira (stem II, perfect passive): to be reminded. (The last two examples may bring about the mental obsession of the reader who may elaborate a version of hieroglyphics.)

جلد Jalada: to whip; jalida: to freeze; jaluda: to be tough; julida (passive perfect of jalada); jallada: to bind a book, to cause to freeze; jaldun: flogging; juldun: leather, skin; jaladun: endurance.

موى Hawā: to tumble, to swoop down (bird); hawiya: to like, to take up as a hobby; hawwā: to ventilate; hawān: affection, desire; hüwan (plural of hüwah): abyss, pit, trench, (fig.) gulf. The pattern of living of the reader may lead his or her mental vowelization.

شمhamāl: left, shimäl: north. This word unvoweled may create a waste of time or energy as one ponders the map or local politics.

\section{Some Further Considerations}

Allah (SWT) has said many times that the Qur'an is an Arabic Qur'an (12:2, 20:133; 39:28, 41:3; 42:7, 43;3; 46:12; 16:103). Its concepts and categories are Arabic. Just as loyalty to Islam cannot be separated from loyalty to al-Qur'ān al-Karim, the latter cannot be separated from loyalty to Arabic, its language and form. ${ }^{18}$

This is a quotation taken from al-Fārūqu's Toward Islamic English, in which he points out the dangers of faulty transliteration and improper translation as serious threats to this continuity of Islamic understanding. $\mathrm{He}$ warns against tolerating the corruption of the Qur'anic language through the use of colloquialisms, whether those of the Arabic or other vernacular:

It is not by accident that every enemy of Islam has blessed, promoted, and encouraged the colloquial dialects of the Muslim peoples. Linguists do know that colloquialisms are the end of 
unity and beginning of division; and those of them that know the continuing role of al-Qur'ān al-Karim has played in uniting the Muslims of the world across the continents as well as the centuries and in determining their lives, do know that colloquialisms cut the umbilical cord which binds the Muslims to their scripture. ${ }^{19}$

We reiterate that, for the sake of competent communication, there is an urgent need for the refinement of rendering the Arabic Islamic texts if the Islamization of knowledge wants to live up to its mission.

Remember that the Arabic language felt alienated in its own culture. The nonvoweled Arabic alphabet was-and is-a convenience for printing information in such foreign languages as German or English. The Arabic language, for the sake of proper utterance, is transliterated, a practice that serves a bridge to the outside world and a transition for some learners of Islam. My motion is that such an unpredictable set of circumstances should be changed. Do not print Arabic consonants only, but print them with the vowels that had been omitted till their very first appearance in the Qur'an for the sake of instruction and preservation of the language and standard recitation (second century A.H./eighth century C.E.).

Indeed, the danger of deviant pronunciations and interpretations and translations coexist wherever there is any toleration of mutilation of the Arabic language. Not including the vowels of the Arabic texts is a manifestation of Jāhiliyah and imbalance in the two readings commanded in Sürat al-Alaq. Vowelization would bring equilibrium to the ummah, which would then be made up of learners-because they were born Muslims or Muslimahs.

Sound thinking is like sound health-a state of being rather than an act of will, according to al-Ghazzăli. Ayurveda nowadays offers, through the works originated and sponsored by Maharishi Mahesh Yogi and his associate researchers, the healing technique of transcendental meditation (TM), quantum healing through the recognition of sound healing. It removes imbalances and obstacles enforced through all encounters. So mind-body healing may take place and, sound health being secured, sound learning may come with Arabic vowels printed, as we plea.

Since the Arabic press for the Qur'an and the Sunnah are in business, there is no problem of cost or lack of experience associated with printing Arabic vowels. Literate people, therefore, are requesting authors to submit vowelized works. Like journalists and scholars, they know first-hand what they mean and how to spell it out completely vowelized. Rules of transliteration, assuming an elementary knowledge of Arabic morphology and syntax on the part of the user, may be a reference for rules of vowelization for the sake of competence communication. ${ }^{20}$

Iqrā'! Read! Proclaim!

Render the Arabic language with its rūh. 


\section{Endnotes}

1. The Random House Dictionary of the English Language (1st ed. unabridged), (New York: Random House, 1966).

2. K. Jamil Ahmad, One Hundred Great Muslims (Chicago: Kazi Publications, 1987), 7.

3. Ismã'il R. al-Fārūqĩ and Lois L. al-Fārūqĩ The Cultural Atlas of Islam (New York: Macmillan, 1986), 100.

4. Ahmad, Great Muslims, 39.

5. Al-Fārūqĩ, Cultural Atlas, 359, illustration 20.1.

6. Ibid., 358, 376. Also see note 4: "Abũ al-Aswad al-Du'ali (d. 69 A.H./688 c.E.) is thought to have invented the system of large colored dots used during the early period of vowel markings. These were supplanted in the eighth century C.E. by the diacritical markings developed by Khahil ibn Ahmad (d. 170 A.H./786 C.E.)."

7. Hans Wehr, A Dictionary of Modern Written Arabic (Beirut: Librarie du Liban, 1980) and his Introduction (Munster: 1960), ix.

8. Tăhă J. al-'Alw̄anī, The Ethics of Disagreement in Islam (Herndon, VA: IIIT, 1993), 85. I refer the reader to chapter 7, "Reasons for Differences," 79-89.

9. Abdullah Y. Ali, The Meaning of the Holy Qur'an: Revised Translation and Commentary (Brentwood, MD: Amana Corporation, 1991), 2:282 and note no. 330.

10. The International Institute of Islamic Thought, Islamization of Knowledge: General Principles and Work Plan, 2d ed. (Herndon, VA: IIIT, 1989), 17, 88, 89, 115.

11. Victoria Fromkin and Robert Rodman, An Introduction to Language (New York: Holt, Rinehart and Winston, 1978), 22. "Without exposure to language children do not speak at all."

12. Deepak Chopra, Sacred Verses, Healing Sounds (San Rafael, CA: New World Library, Quantum Publications, 1994). 2 cassettes, vol. 1: "The Bhagavad Gita".

13. Emest MacCarus and Raji Rammuny, A Programmed Course in Modern Literary Arabic: Phonology and Script (Ann Arbor, MI: University of Michigan, 1974), 165-66.

14. Marshall G. S. Hodgson, The Venture of Islam, vol. 2: The Expansion of Islam in the Middle Periods (Chicago: University of Chicago Press, 1974), 325.

15. IIIT, Islamization of Knowledge, introduction, p. x.

16. Ṭāhã J. al-'Alw̄anī, "The Islamization of Knowledge: Yesterday and Today," American Journal of Islamic Social Sciences 12, no. 1 (Winter 1995): 85-88.

17. Muhammad Yusrā Zuhayr, Fann Tasrîf, Fann al-Lughah al-'Arabìyah (Dār Ihyãa' al-Kutub al-'Arabiyah, 1408/1987), 2:44-53. I audited the course at the College of Islamic and Arabic Studies, al-Azhar University (women's section), Cairo, during 1988-89.

18. Ismāîl R. al-Fārūqī, Towards Islamic English (Herndon, VA: IIIT, 1986), Islamization of Knowledge Series 3:13.

19. Ibid., 14.

20. See Wehr, Introduction, xiv. 